\title{
Amyloid Beta Peptide Is Released during Thrombosis in the Skin
}

\author{
Lilia Y. Kucheryavykh ${ }^{1}$, Yuriy V. Kucheryavykh ${ }^{1}$, A. Valance Washington ${ }^{2}$ \\ and Mikhail Y. Inyushin ${ }^{3, * \text { iD }}$ \\ 1 Department of Biochemistry, School of Medicine, Universidad Central del Caribe, PO Box 60327, \\ Bayamon, PR 00960-6032, USA; lilia.kucheryavykh@uccaribe.edu (L.Y.K.); \\ yuriy.kucheryavykh@uccaribe.edu (Y.V.K.) \\ 2 Department of Biology, University of Puerto Rico Rio Piedras, San Juan, PR 00936-8377, USA; \\ anthony.washington@upr.edu \\ 3 Department of Physiology, School of Medicine, Universidad Central del Caribe, PO Box 60327, \\ Bayamon, PR 00960-6032, USA \\ * Correspondence: mikhail.inyushin@uccaribe.edu; Tel.: +1-787-6676-469
}

Received: 3 April 2018; Accepted: 6 June 2018; Published: 8 June 2018

\begin{abstract}
While it is known that amyloid beta $(\mathrm{A} \beta)$ deposits are found in different tissues of both Alzheimer's disease (AD) patients and healthy individuals, there remain questions about the physiological role of these deposits, the origin of the $A \beta$ peptide, and the mechanisms of its localization to the tissues. Using immunostaining with specific antibodies, as well as enzyme-linked immunosorbent assay, this study demonstrated A $\beta 40$ peptide accumulation in the skin during local experimental photothrombosis in mice. Specifically, A $\beta$ peptide accumulation was concentrated near the dermal blood vessels in thrombotic skin. It was also studied whether the released peptide affects microorganisms. Application of A $\beta 40(4 \mu \mathrm{M})$ to the external membrane of yeast cells significantly increased membrane conductance with no visible effect on mouse host cells. The results suggest that $A \beta$ release in the skin is related to skin injury and thrombosis, and occurs along with clotting whenever skin is damaged. These results support the proposition that $A \beta$ release during thrombosis serves as part of a natural defense against infection.
\end{abstract}

Keywords: natural peptide antibiotic; $\mathrm{A} \beta 40$ peptide; skin; thrombosis

\section{Introduction}

In 1906, Dr. Alois Alzheimer showed that amyloid beta $(A \beta)$ peptide is the major constituent of amyloid plaques in the brain, thus implicating these peptides in Alzheimer's disease (AD) [1]. $\mathrm{A} \beta$ peptide and its $\beta$-sheet conglomerates were found not only in the brain, but also between muscle fibers associated with skeletal muscle myopathy [2,3] and in the eye [4-6]. In some cases of idiopathic cardiomyopathy, the presence of $\mathrm{A} \beta$ peptide in myocardium was also significantly increased in AD [7]. $\mathrm{A} \beta$ protein deposits in the skin were described many years ago, in and around the endothelium of dermal blood vessels in aged AD patients, and were proposed as a marker for this disease [8]. Later, skin accumulation of $A \beta$ around blood vessels was found to be unrelated to the severity of symptoms in AD patients, occurring also in some healthy subjects [9]. Some authors also suggested a relationship between $A \beta$ deposits in the skin and the occurrence of amyotrophic lateral sclerosis, as $\mathrm{A} \beta$ was detected in the skin of these patients at a higher level than in healthy individuals [10]. Two decades ago, Joachim et al. (1989) [8] pointed out that the source of A $\beta$ deposits in the skin and other organs was probably a common blood-borne precursor. Recently, we showed that activated blood platelets aggregated in blood clots contribute to the accumulation of $A \beta$ peptide in the brain: 
$\mathrm{A} \beta$ peptide was found in and around brain blood vessels in mice after thrombosis, as revealed by immunostaining, while in thrombocytopenic animals, this release was severely reduced [11].

Skin thrombosis is normally a defense against traumatic injury and/or a response to a number of other septic and aseptic causes that activate platelets in the skin and initiate the coagulation cascade. It is known that, besides coagulation factors, platelets also contain a relatively high concentration of amyloid precursor protein (APP), which mostly accumulates within $\alpha$-granules, and full-length APP (containing A $\beta$ peptide) is liberated upon platelet degranulation [12-16]. APP is itself a Kunitz-type protease inhibitor, which effectively inhibits chymotrypsin, trypsin, and other proteolytic enzymes $[13,17,18]$, and promotes the activation of coagulation factor XII $[19,20]$. Therefore, platelet-released APP is likely to play an important role in the hemostasis and temporal stability of the thrombus [19].

Platelets are also the primary source $(\sim 90 \%)$ of $\mathrm{A} \beta$ peptide in human blood [21], while the $A \beta$ peptide variants secreted by platelets are similar to those found in the senile plaques of $A D$ patients [22]. When densely concentrated, platelets secrete mainly $A \beta$ ending at residue 40 (A $\beta 40)$ as a final product, while the production of $A \beta 42$ does not depend on platelet concentration [23]. Recently, it was shown that $A \beta$ peptide has strong antibiotic activity against both Gram-negative and Gram-positive bacteria, as well as fungi and viruses [24-27]. A $\beta$ peptide also protects mice against microbial infection in in vivo experiments [28]. Based on these findings, it was suggested that $A \beta$ is a previously unrecognized antimicrobial agent that normally functions in the innate immune system $[11,24,28,29]$. However, $A \beta$ peptide is not the only weapon in the platelet arsenal, as other antibacterial peptides were identified long ago [30-34]. Like $A \beta$, one of these antibacterial peptides (platelet microbicidal protein 1) has a variable length of either 72 or 73 amino acids, and is cleaved from a longer precursor [35].

While it was proposed that $A \beta$ peptide oligomers aggregated into blood clot fibrils entrap microbes [28], we suggested another mechanism related to the plasma membrane pore-forming properties of $A \beta$ peptide $[11,29]$. It was shown that soluble $A \beta$ peptide oligomers at low concentrations perforate cell membranes by forming tetramer channels penetrable by $\mathrm{K}^{+}$ions, and do so at higher concentrations by forming $\mathrm{Ca}^{2+}$-permeable hexameric pores [36-38]. An excess of $\mathrm{Ca}^{2+}$ permeability through these pores induces calcium dyshomeostasis, leading to cell death [39]. The same mechanism is employed by other natural peptide antibiotics with channel-forming activity, such as amphotericin B and nystatin [40,41].

We hypothesize that A $\beta$ peptide (cleaved from the released APP or directly released by platelets) may form a sufficient number of large pores in the microbe plasma membrane to cause the death of the microorganism, thereby acting as part of the body's defense system to prevent infection. This mechanism might be of special importance in the skin, which is the organ forming the initial defensive barrier.

Immunostaining and enzyme-linked immunosorbent assay (ELISA) methods were used in this study for in vivo evaluation of the release of $A \beta$ in mouse skin during local experimental thrombosis. Patch-clamp electrophysiology methods were used to study the conductivity of the fungal cell membrane after the application of $A \beta 40$ peptide. Mouse astrocytes were used as control eukaryotic host cells for the evaluation of the pore-forming activity of $A \beta 40$ in eukaryotic cell plasma membranes.

\section{Results}

\subsection{A Immunoreactivity Was Concentrated in Dermal Blood Vessels a Few Minutes after Thrombosis Activation in the Skin and Became More Diffuse Later}

To study the distribution of $A \beta$ peptide in skin after thrombosis, we applied a standard model of photo-induced coagulation to obtain thrombotic clots in skin blood vessels. Mice were injected intraperitoneally with the photoactivated dye Rose Bengal, and the bruised spot became visible after application of intense green laser light to the shaved skin. Immunocytochemical evaluation of coagulated and control skin samples revealed $A \beta$ immunofluorescence in and around blood vessels 
(Figure 1), and mainly coinciding with the boundaries of the vessels. Some diffuse green staining of $\mathrm{A} \beta$ emanating from the vessels is also visible, as well as small parts of (apparently) other blood vessels.

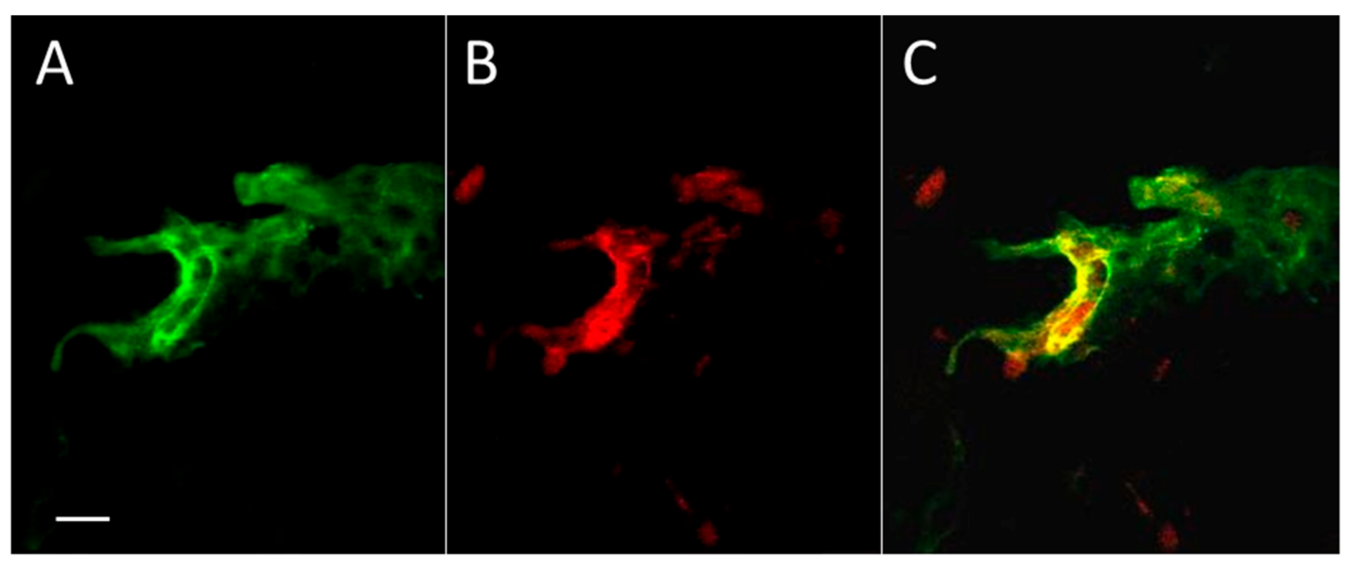

Figure 1. $A \beta$ in the zone of experimental thrombosis in a mouse skin section. In addition, there is some diffuse anti-A $\beta$ staining around the vessels. (A) The immunoreactivity against $\mathrm{A} \beta$ peptide (green); (B) The luminal surface of skin blood vessels marked by climbing shrub lectin (Rose Bengal, red); (C) Red + green = yellow color reveals the significant coincidence of $A \beta$ immunoreactivity and blood vessel surface staining. Bar, $10 \mu \mathrm{m}$.

The distribution pattern of $\mathrm{A} \beta$ immunofluorescence in thrombotic (Figure 2A) and control (Figure 2B) skin was markedly different. The blood vessel stained for $A \beta$ can be distinguished near the hair follicle (Figure 2A1), while similarly processed control skin has only a very low level of relatively uniform $A \beta$ immunofluorescence that is not visible at the same threshold value (Figure 2B1). The line segment 1-2 (Figure 2A1) crosses the blood vessel, and the profile of green fluorescence along this line in Figure $2 \mathrm{~A} 2$ shows $A \beta$ diffusion from the blood vessel. The distribution of $A \beta$ immunofluorescence along the randomly drawn 1-2 line segments in control skin (Figure 2B1) shows only a very low level of relatively uniform $A \beta$ immunofluorescence (Figure 2B2).

The 3D distribution of $A \beta$, which is mainly concentrated within the large and small blood vessels, but to some extent leaks into the nearby tissue, is shown in Figure S1. Interestingly, erythrocytes were stained as $A \beta$-positive in a thrombotic skin sample (Figure S1). It is known that $A \beta$ peptide in blood plasma binds to $98 \%$ of all erythrocytes in AD patients, and is a marker of the disease [42]. Moreover, the addition of synthetic $\mathrm{A} \beta$ not only marks erythrocyte membranes, but also makes them more elongated [43].
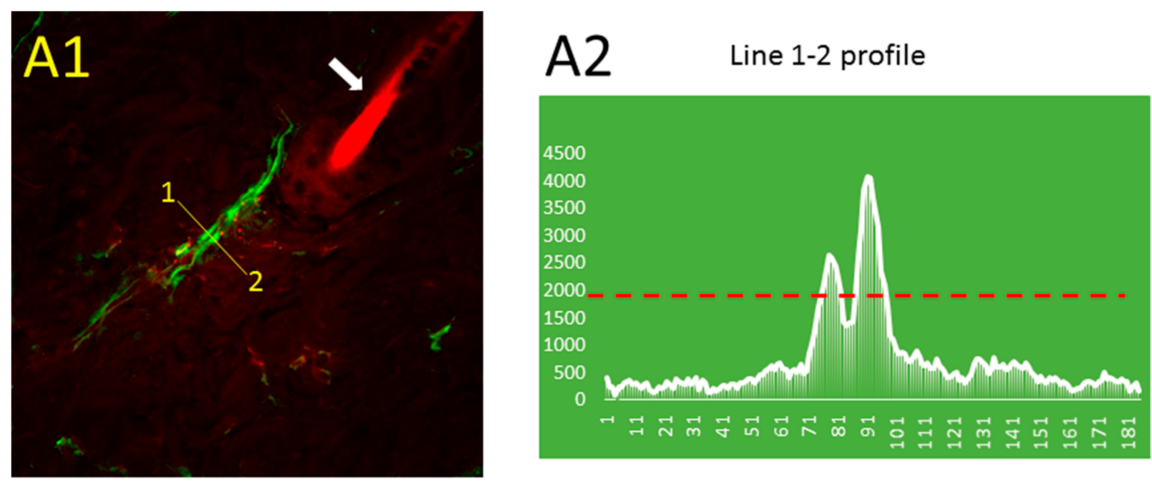

(A)

Figure 2. Cont. 

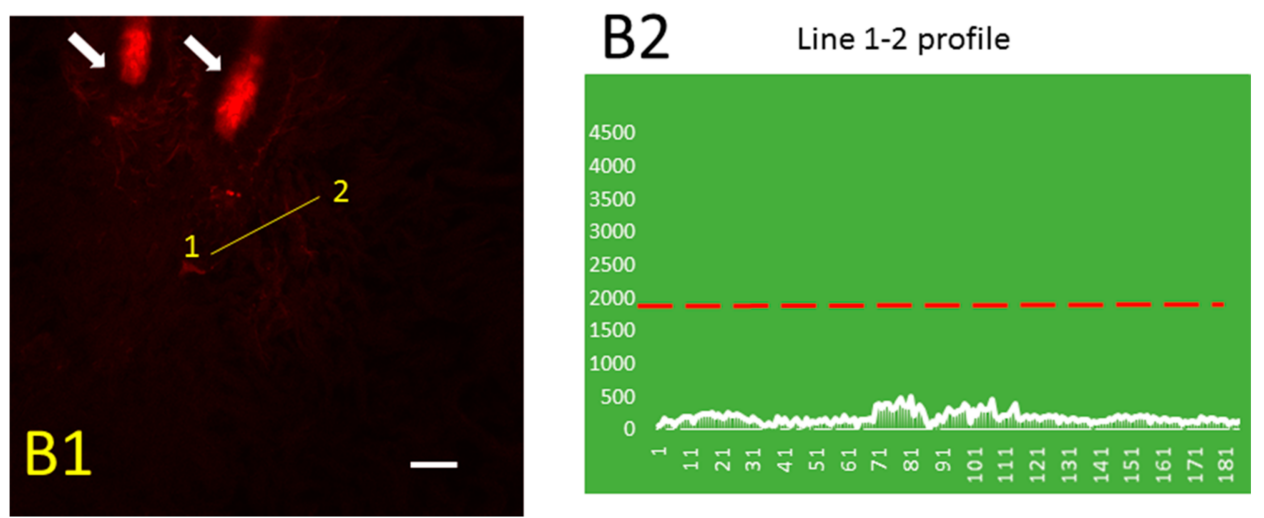

(B)

Figure 2. Distribution pattern of $A \beta$ (green) immunofluorescence and blood vessel (red) fluorescence in thrombotic (A1) and control (B1) skin and the $A \beta$ peptide profile (along line segment 1-2) in thrombotic (A2) and control (B2) skin in $0.5 \mu \mathrm{m}$ steps. Green, immunofluorescence bound to A $\beta$ peptide; red, Rose Bengal dye fluorescence bound to the luminal surface of blood vessels. Arrows, hair bulbs with visible hair shafts. The dashed red line in (A2) and (B2) indicates the intensity threshold of the green channel used in (A1) and (B1). Bar, $20 \mu \mathrm{m}$.

\subsection{Formation of Blood Clots in the Skin Augments the Quantity of A $\beta$ Peptide in Thrombotic Skin}

To determine the levels of mouse-specific A $\beta 40$ peptide in skin patches in control and post-photothrombosis skin a commercially available enzyme-linked immunosorbent assay (ELISA) was used. The final concentrations of $\mathrm{A} \beta 40$ in control $(415 \pm 57 \mathrm{pg} / \mathrm{mL})$ and thrombotic $(1733 \pm 165.7 \mathrm{pg} / \mathrm{mL})$ skin indicate an $\sim 4$-fold increase after thrombosis (Figure $3, n=4, p<0.001$, $t=8.549, \mathrm{df}=5)$.

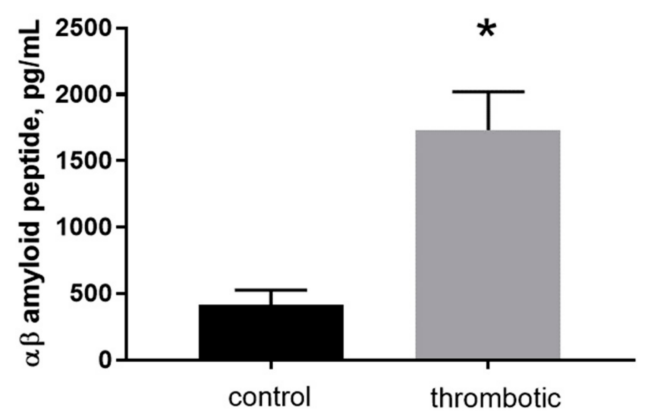

Figure 3. The concentration of free mouse $A \beta 40$ peptide determined by enzyme-linked immunosorbent assay (ELISA) in control and thrombotic skin homogenate $(\mathrm{pg} / \mathrm{mL})$. Mean \pm S.E. and significant differences between groups $(*)$ are shown $(p<0.05)$.

\subsection{Application of A $\beta 40$ to the External Membrane of Yeast Cells Visibly Augmented Membrane Conductance}

Patch-clamp measurements with electrodes filled with synthetic A $\beta 40$ were used in order to evaluate the effect of $A \beta 40$ on membrane conductance in microorganisms. Yeast cells were selected as a model, because these microorganisms have the cell size and other characteristics that allow for the measurement of external membrane conductance using the patch-clamp technique (Figure 4B). Fine-tip electrodes ( 10-12 M $\Omega$ tip resistance) were employed in the cell-attached voltage-clamp configuration without rupturing the cellular membrane. In this configuration, the cell is attached to the electrode with holding potential $\mathrm{U}$, which is changed according to the protocol. 

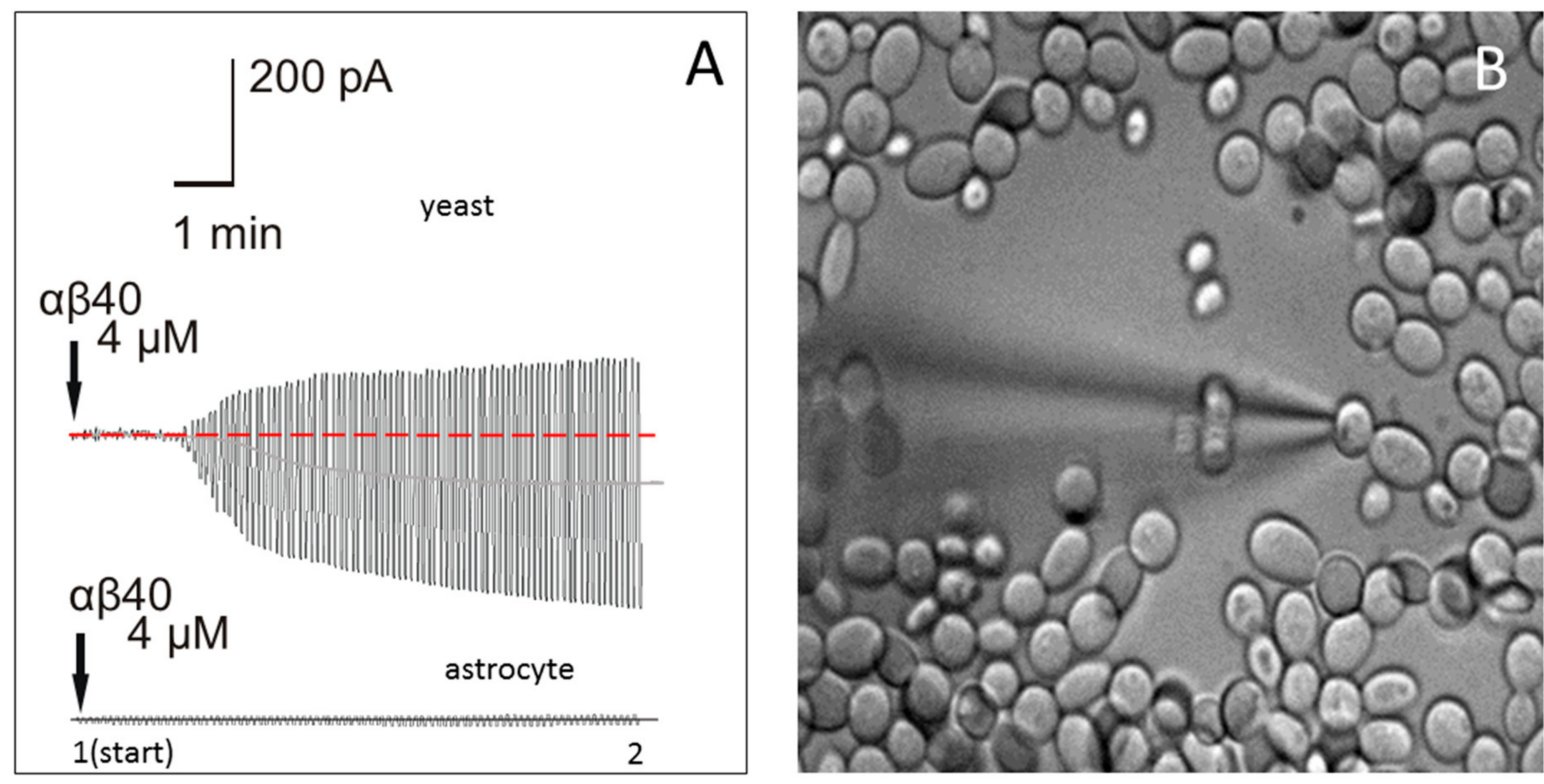

Figure 4. (A) Membrane currents in the cell-attached configuration in a yeast cell (upper trace) and a mouse astrocyte cell (lower trace) after $\mathrm{A} \beta 40$ peptide $(4 \mu \mathrm{M})$ was added to the pipette solution and a test periodic voltage of $\pm 100 \mathrm{mV}$ was applied to the pipette; (B) Patch-clamp of yeast cells visualized with a difference interference contrast (DIC) microscope with $40 \times$ water immersion objective. Diameter of yeast cells, 3-4 microns.

The current passing first through the electrode (R-elect = $10 \mathrm{M} \Omega$ ), then (serially) through the patch of cellular membrane (R-patch), and then through the rest of the membrane (R-mem), is measured. A pore-former would affect only R-patch, while other resistances would stay constant, and an R-patch change would affect the total membrane current I (Figure 4A). Channel-forming peptides are not anchored, and rapidly diffuse around lipid membranes, forming temporary ion channels $[44,45]$. The resistance of the membrane patch perforated by a channel-former decreases, leading to a current increase. This resistance, and its changes with time, are calculated by measuring the current at the beginning (after attachment, time 1, Figure $4 \mathrm{~A}$ ) and after the effect is pronounced (time 2, Figure $4 \mathrm{~A}$ ), in which $\mathrm{R}=\mathrm{U} / \mathrm{I}$, and the resistance change with time (Rtime1/Rtime2) can be calculated.

Four different concentrations of $\mathrm{A} \beta 40(0.4 \mathrm{nM}, 40 \mathrm{nM}, 400 \mathrm{nM}$, and $4 \mu \mathrm{M})$ were tested. While nanomolar concentrations of $\mathrm{A} \beta 40$ had no pronounced effect, $4 \mu \mathrm{M} A \beta 40$ produced visible augmentation of the current amplitude from $20 \mathrm{pA}$ to about $400 \mathrm{pA}$ (Figure 4A, upper trace), which developed at 3-5 min after application. The effect was statistically significant, as 4 min after the electrode containing $A \beta 40$ was attached to the yeast membrane, the resistance was reduced $17.4 \pm 3.1$-fold $(n=7, p<0.0001, t=245.7, \mathrm{df}=12)$. These changes in current indicate that the yeast membrane resistance was rapidly and significantly affected by the application of $A \beta 40$.

\subsection{Application of A $\beta 40$ to the External Membrane of Mouse Astrocytes Did Not Significantly Affect Membrane Conductance}

A standard patch-clamp was used in cell-attached configuration to study whether A $\beta 40$ affects mouse cell membrane conductance at the same concentration as in yeast cells $(4 \mu \mathrm{M})$. Astrocytes in a mouse hippocampus brain slice were used as the model. After an electrode containing $4 \mu \mathrm{M}$ A $\beta 40$ was attached to an astrocyte membrane (Figure $4 \mathrm{~A}$, lower trace), the transverse current in the astrocyte external membrane was not significantly affected $3-5$ min after application $(n=8, p=0.7584, t=0.3136$, $\mathrm{df}=14)$. Thus, at a $4 \mu \mathrm{M}$ concentration, $\mathrm{A} \beta 40$ had no immediate effect on the membrane resistance of astrocytes. 


\section{Discussion}

This study established a correlation between the release of $A \beta$ and thrombotic processes in mouse skin. Experimental photothrombosis was used, which is a well-established method for inducing rapid coagulation without mechanical damage to the tissue $[11,46]$.

Immunostaining with a MOAB-2 (monoclonal mouse anti-A $\beta$ antibody) confirmed that by 10 min after thrombosis, $\mathrm{A} \beta$ was present mainly in and around blood vessels in the skin (Figure 1, Figure 2 and Figure S1). The MOAB-2 antibody was chosen because of the high specificity to A $\beta$ peptide. This antibody was extensively tested, previously, and found to be a pan-specific, high-titer antibody to $A \beta$ residues 1-4, reacting with unaggregated, oligomeric, and fibrillar forms of $A \beta 42$ and unaggregated $\mathrm{A} \beta 40$, as well as with aggregated amyloid in plaques $[47,48]$. The MOAB-2 anti-A $\beta$ antibody did not detect APP or its derivatives, and did not colocalize with antibodies against either the N- or C-terminal of APP [47]. It is a technical challenge to stain the endothelial cells of blood vessels to study colocalization of $A \beta$ and the blood vessel boundaries after thrombosis. The commonly used markers for blood vessel endothelium, CD31, von Willebrand factor (vWF), and CD34, are not suitable for staining endothelial cells in this model of platelet aggregation, because they are upregulated at the membranes of activated platelets in the clot, or are involved in platelet-vessel wall interactions, producing confusion [49-51]. For this reason, isolectin B4 (BSI-B4) from Bandeiraea simplicifolia was selected as the most suitable marker for the luminal surfaces of endothelial cells [52-54] in thrombotic models. Unlike thrombotic skin (Figure 2A1), in which the blood vessels were clearly marked with $A \beta$ immunofluorescence, in control skin (Figure 2B1) there was no visible co-staining of A $\beta$ and blood vessels or other structures. The $A \beta$ immunofluorescence profile declined rapidly away from the blood vessel boundaries (Figure 2A2), while it stayed uniformly low in control skin (Figure 2B2).

Additionally, the study revealed that experimental thrombosis resulted in a 4-fold elevation of $\mathrm{A} \beta$ in skin, reaching $1733 \pm 165.7(\mathrm{pg} / \mathrm{mL})$, which is about $0.4 \mathrm{nM}$. This concentration is in the range previously reported for $A \beta$ in the cerebrospinal fluid (CSF) of young genetically modified 3xTg-AD mice, which spontaneously develop brain plaques [55]. The A $\beta 40$ concentration in control skin in our experiments was $415 \pm 57(\mathrm{pg} / \mathrm{mL})$, which is close to the range of concentrations $(340-550 \mathrm{pg} / \mathrm{mL})$ previously found in the blood plasma of healthy humans [56-58]. Measurement of $A \beta$ in blood by ELISA reveals mainly free peptides, while a significant amount of $A \beta$ peptide remains bonded to plasma proteins and lipoproteins [59], as well as to cell membranes [42], and our estimation of $\mathrm{A} \beta 40$ in skin has similar limitations. The detection of $\mathrm{A} \beta$ peptide generation in the skin is consistent with the hypothesis that a role of $\mathrm{A} \beta$ is as a natural defense against infection that accompanies thrombosis. The pore-forming properties of innate $\mathrm{A} \beta$ peptide might provide a rapid antimicrobial defense mechanism [11,29]. The current study provides additional support for this hypothesis, indicating that $A \beta 40$ peptide significantly affects the conductivity of fungal membranes. Application of $4 \mu \mathrm{M} A \beta 40$ to the external wall of yeast cells produced marked augmentation of the recorded current amplitudes (Figure 4A). Bertl et al. (1998) [60] first described the method for patch-clamping yeast cells without cell wall removal, showing that it forms a standard gigaseal. It is known that the fungal cell membrane is mechanically protected by a cell wall that is impossible to "open" by pressure application only $[60,61]$. Thus, the cell-attached configuration was used to record membrane currents, enabling this problem to be overcome. In yeast cells, a change in membrane resistance developed 2-5 min after peptide application, and became saturated after reaching a new limit. It should be mentioned also that the recommended Tris [tris(hydroxymethyl)aminomethane] buffer [60] was switched to HEPES [4-(2-hydroxyethyl)-1-piperazineethanesulfonic acid], because Tris buffer effectively blocks A $\beta$ peptide-formed channels [62]. At the same time, the similar patch-clamp configuration and $A \beta 40$ concentration had no effect on the resistance of the mouse astrocyte (host cell) external plasma membrane (Figure 4).

The pore-forming effect of $A \beta$ peptide on brain cell membranes is well known $[63,64]$. The pronounced effect of $\mathrm{A} \beta 40$ in yeast $(4 \mu \mathrm{M})$, but not in eukaryotic host cells in the current study, may reflect the fact that yeast cells have less cholesterol and more ergosterol in their membranes 
than mammalian cells [65], and it was previously found that membrane cholesterol reduces $A \beta 40$ channel-forming activity [66].

Interestingly, there is a significant mismatch between $A \beta 40$ peptide concentration found in the skin after thrombosis and its effective antimicrobial concentration. The results of this study demonstrate that, when $\mathrm{A} \beta 40$ is released in the skin during thrombosis, the concentration detected $(\sim 0.4 \mathrm{nM})$ is lower than necessary for a significant membrane effect in Saccharomyces yeast $(4 \mu \mathrm{M})$. It was previously shown that pathologic Candida yeast are more sensitive to $A \beta 40$ peptides $(0.78 \mu \mathrm{g} / \mathrm{mL}$, [24]); however, this was 1200 -fold more than the concentration detected in the current study in thrombotic skin. At the same time, other antibacterial peptide species that were identified in platelets were found to be very effective against bacteria when applied in nanomolar concentrations as a thrombin-induced platelet supernatant, while purified proteins were effective in the 10-40 $\mu \mathrm{M}$ range [31,35]. Similarly, one might assume that the sensitivity of microorganisms to the native $A \beta$ peptide would be significantly higher than the synthetic peptide.

Another explanation of this contradiction might be that the $A \beta 40$ concentration that was determined by ELISA in mouse skin was not the local concentration around the damaged blood vessels, but rather the mean concentration in tissue. $A \beta 40$ is mostly concentrated locally around blood vessels (Figure 2A,B), and rapidly declines away from the blood vessel boundary.

Many factors affect the sensitivity of microorganisms to A $\beta 40$. First, the amount of oligomerized A $\beta 40$ peptides depends on the solubilization method and the peptide form used in experiments. Oligomer formation by $\beta$-sheeting of monomeric $A \beta$ is the necessary first step in forming $\mathrm{Ca}^{2+}$-permeable ion channels $[67,68]$. As an example, Candida yeast are very sensitive to $\mathrm{A} \beta$ peptides $\left(0.78 \mu \mathrm{g} / \mathrm{mL}\right.$, [24]), but the recommended solubilization of the peptide with $\mathrm{NH}_{4} \mathrm{OH}$ [69] reportedly may lead to a lack of toxic effects at low concentrations [70], which supports the possibility that the solubilization method affects the oligomerization of $A \beta$.

Second, $A \beta 40$ peptide carriers also reduce the effective concentration for pore formation. It was shown that in blood plasma, $A \beta$ is usually attached to carriers, while unbound $A \beta$ is rare. In blood plasma, A $\beta 40$ was found bound to several proteins (that is, apolipoproteins A-I, A-IV, E and J; $\alpha 2$-macroglobulin; complement factors; immunoglobulins; transthyretin; apoferritin; and serum amyloid $\mathrm{P}$ component [71-73]), and one carrier is associated with many A $\beta$ peptide molecules [74]. It is possible that if a carrier transports numerous $A \beta 40$ peptide molecules to the cellular membrane and fuses to the membrane, it will drastically augment the local effective concentration of $A \beta$ and result in pore formation. This carrier-based reduction of the bulk-phase $A \beta 40$ concentration necessary for pore formation has been shown previously in artificial membranes [75]. When $A \beta$ was concentrated inside liposomes, it was incorporated into plasma membranes more readily than by direct incorporation from aqueous solution.

We suggest that under natural conditions, blood plasma has liposome-like components, such as tissue-specific apolipoprotein type E (APOE), that facilitate the membrane-damaging action of amyloid-prone proteins and peptides. Under normal conditions, APOE participates in lipid transport and removes cholesterol and triglycerides from peripheral tissues. Many cell types produce APOE, including skin epithelium cells [76-78]. APOE was found in skin tissue, and plays an important role in primary localized cutaneous amyloidosis (PLCA) formation [79], which is associated with $\alpha \beta$ deposits, as well as with deposits of misfolded amyloid-like keratin peptides [80]. Interestingly, the E4 allele of APOE is significantly increased in frequency in patients with PLCA [81], and similarly, the E4 allele is increased in frequency in AD [82]. Thus, APOE involvement in both types of amyloidosis makes it the main suspect as the amyloid peptide carrier and possible facilitator of the pore-forming effects of these peptides.

\section{Materials and Methods}

All procedures involving rodents were conducted in accordance with the National Institutes of Health regulations concerning the use and care of experimental animals. All procedures involving 
animals were approved by Universidad Central del Caribe Institutional Animal Care and Use Committee (Protocol \#035-2017-16-01, 16 January 2017). All efforts were made to minimize suffering. For skin thrombosis experiments, animals were anesthetized with isoflurane (4\% for induction, $1.75 \%$ for maintenance) using a Matrix Quantiflex VMC Anesthesia Machine for small animals (Midmark Corp., Dayton, OH, USA). After photothrombosis experiments, the anesthetized animals were rapidly decapitated and skin patches harvested. This euthanasia method is consistent with the recommendations of the Panel on Euthanasia of the American Veterinary Medical Association. In total, 12 C57BL/ 6 mice were used in these experiments.

\subsection{Photothrombosis Model}

In order to induce clot formation in mouse skin, a widely used method of photostimulated thrombosis was employed [11,46]. C57BL/ 6 mice of both sexes, 8-10 weeks old, were used in experiments. Briefly, prior to surgery, Rose Bengal (cat. \#198250; Sigma-Aldrich Chemical Co., St. Louis, MO, USA) was dissolved in a sterile saline solution $(7.5 \mathrm{mg} / \mathrm{mL})$. The mice were then anesthetized with isoflurane, followed by peritoneal injection of Rose Bengal ( $150 \mu \mathrm{g} / \mathrm{g}$ animal weight), which was allowed to diffuse and enter the blood stream for $5 \mathrm{~min}$. The animal skin was shaved and exposed to a laser beam (15 $\mathrm{mW}$ at $430 \mathrm{~nm}$ ) until a visible bruise appeared on the skin (in 10-15 min). The resulting thrombosis was 3-4 $\mathrm{mm}$ in diameter. The mice were killed, and control and thrombotic skin samples were harvested and fixed in 5\% formaldehyde as soon after thrombosis formation (which takes $\sim 10 \mathrm{~min}$ ) as possible. Interestingly, alone among the many xanthene dyes, Rose Bengal exhibited a strong inhibitory effect on $A \beta$ aggregation upon green photoexcitation, because of its high binding affinity for $A \beta$, and it also exhibits a remarkable red shift and a strong enhancement of fluorescence emission in the presence of $A \beta$ [83]. Thus, Rose Bengal fluorescence is an indicator of the presence of $A \beta$.

\subsection{Mouse Brain Slice Preparation}

Mice ( 3 months old) were decapitated, and the brains were removed from the skull in ice-cold $\left(2-4{ }^{\circ} \mathrm{C}\right.$ ) dissecting solution composed of (in $\mathrm{mM}$ ): $126 \mathrm{NaCl} ; 2.5 \mathrm{KCl} ; 1.2 \mathrm{NaH}_{2} \mathrm{PO}_{4} ; 7.0 \mathrm{MgCl}_{2}$; $0.5 \mathrm{CaCl}_{2} ; 25$ glucose; $25 \mathrm{NaHCO}_{3}$; and saturated with $95 \% \mathrm{O}_{2}$ and $5 \% \mathrm{CO}_{2}$. The hippocampal area from 4 animals were used for the brain slice preparations. Brain tissues were sectioned, and $250 \mu \mathrm{m}$ slices were cut using a Vibroslicer (Leica VT 1000S, Leica Microsystems, Wetzlar, Germany). The slices were placed in an incubation chamber containing oxygenated artificial cerebrospinal fluid (ACSF; in mM: $126 \mathrm{NaCl} ; 2.5 \mathrm{KCl} ; 1.2 \mathrm{NaH}_{2} \mathrm{PO}_{4} ; 1.0 \mathrm{MgCl}_{2} ; 2.0 \mathrm{CaCl}_{2} ; 25$ glucose; $25 \mathrm{NaHCO}_{3}$; and saturated with $95 \% \mathrm{O}_{2}$ and $5 \% \mathrm{CO}_{2}$ ) at $35{ }^{\circ} \mathrm{C}$, and incubated at least $60 \mathrm{~min}$ before recording. Next, the slices were placed in the recording chamber $(500 \mu \mathrm{L})$ and perfused with $\operatorname{ACSF}\left(35^{\circ} \mathrm{C}\right)$ at a rate of $2 \mathrm{~mL} / \mathrm{min}$.

\subsection{Preparation of Fungi (Yeast) for Patch-Clamping of Plasma Membrane}

A common haploid S. cerevisiae yeast strain (BY4741) was used for patch-clamp experiments. Cells were grown overnight in a small volume of modified liquid YEPD medium (1\% yeast extract, $2 \%$ peptone, and 5\% D-glucose; cat. \#Y1375; Sigma-Aldrich, St. Louis, MO, USA), with $30 \mathrm{~mL}$ per $125 \mathrm{~mL}$ Erlenmeyer flask at $25{ }^{\circ} \mathrm{C}$ with rotary shaking $(90 \mathrm{rpm})$. The cells were harvested by centrifugation $(500 \times \mathrm{g}$ for $5 \mathrm{~min}$ ) of $1 \mathrm{~mL}$ of suspension, and were then resuspended in the following buffer: $140 \mathrm{mM} \mathrm{NaCl}, 5 \mathrm{mM} \mathrm{MgCl}, 10 \mathrm{mM} \mathrm{CaCl}_{2}, 10 \mathrm{mM}$ HEPES, adjusted to $\mathrm{pH} 7.5$ with $\mathrm{KOH}$. A few drops of this suspension were finally added to the patch-clamp chamber with the same buffer. Patch recording was done according to the method developed for S. cerevisiae by Bertl et al. (1998) [60] with modifications. The most important modification was the use of HEPES buffer instead of Tris, as Tris is a well-known blocker of A $\beta$ channels [62]. Another modification was the use of the cell-attached patch-clamp procedure instead of whole-cell patch-clamp. Cells were visualized using an Olympus infrared microscope equipped with a difference of interference contrast (DIC) system (cat. \#BX51WI; Olympus, Japan). Placed in the chamber, the cells sedimented rapidly, and under the 
microscope, cells ( $3-4 \mu \mathrm{m}$ in diameter) were selected for patch-clamping. Borosilicate glass pipettes (O.D., $1.5 \mathrm{~mm}$; I.D., $1.0 \mathrm{~mm}$; World Precision Instruments, Sarasota, FL, USA) were pulled in four steps to a final resistance of 10-12 M $\Omega$ for recordings using a P-97 puller (Sutter Instrument Co., Novato, CA, USA). Electrodes were filled with the following solution: $175 \mathrm{mM} \mathrm{KCI}, 5 \mathrm{mM} \mathrm{MgCl}{ }_{2}$, $4 \mathrm{mM}$ ATP, $100 \mathrm{nM} \mathrm{Ca}{ }^{2+}, 1 \mathrm{mM}$ EGTA, and brought to $\mathrm{pH} 7.0$ with $\mathrm{KOH}$. The necessary A $\beta$ concentration was then added to this buffer. Currents were recorded in response to $2 \mathrm{~s}$ voltage steps, switching from +100 to $-100 \mathrm{mV}$, with a $2 \mathrm{~s}$ holding interval at $0 \mathrm{mV}$ between each pulse. Results are presented as concatenated response curves. Data were filtered at $1 \mathrm{kHz}$ and sampled at $100 \mathrm{~Hz}$ during recording, and the presentation data were then filtered at $40 \mathrm{~Hz}$. The pipette potential was not corrected.

\subsection{Whole-Cell Recordings in Astrocytes}

Membrane currents were measured using the single-electrode, whole-cell patch-clamp technique. Cells were visualized using an Olympus infrared microscope equipped with a DIC system (cat. \#BX51WI; Olympus, Japan). A piezoelectric micromanipulator (MX7500 with MC-1000 drive; Siskiyou, Inc., Grants Pass, OR, USA) was used for voltage-clamp and current-clamp recording, and allowed the patch clamping of cells. A MultiClamp 700A patch-clamp amplifier with two separate patch-clamp channels paired to a DigiData 1322A interface (Molecular Devices, Inc., Sunnyvale, CA, USA) was used for recording and stimulation. The pClamp 10 software package (Molecular Devices, Inc.) was used for data acquisition and analysis. Borosilicate glass pipettes (O.D., $1.5 \mathrm{~mm}$; I.D., $1.0 \mathrm{~mm}$; World Precision Instruments; Sarasota, FL, USA) were pulled to a final resistance of 7-8 $\mathrm{M} \Omega$ for recordings in four steps using a P-97 puller (Sutter Instrument Co., Novato, CA, USA). Electrodes were filled with the following solution (in $\mathrm{mM}$ ): $130 \mathrm{~K}$-gluconate, $10 \mathrm{Na}$-gluconate, $4 \mathrm{NaCl}, 4$ phosphocreatine, $0.3 \mathrm{GTP}-\mathrm{Na}_{2}, 4 \mathrm{Mg}$-ATP, and $10 \mathrm{HEPES}$, and the $\mathrm{pH}$ was adjusted to 7.2 with $\mathrm{KOH}$. Currents in the cell-attached configuration were recorded in response to $2 \mathrm{~s}$ voltage steps, switching from +20 to $-20 \mathrm{mV}$, with a $2 \mathrm{~s}$ holding interval at $0 \mathrm{mV}$ between each pulse. Data were filtered at $1 \mathrm{KHz}$ and sampled at $100 \mathrm{~Hz}$ during recording. The presentation data were then filtered at $40 \mathrm{~Hz}$, and the pipette potential was not corrected.

\subsection{Preparation of $A \beta$ Peptide Solution}

We used lyophilized synthetic A $\beta 40$ peptide trifluoroacetate salt (cat. \#A4473; Sigma-Aldrich, St. Louis, MO, USA), and the $40 \mu \mathrm{M}$ stock solution $(\sim 0.18 \mathrm{mg} / \mathrm{mL})$ was prepared from the peptide on the day of experimentation by solubilizing $A \beta 40$ in a buffer similar to electrode internal solution (see Sections 2.2 and 2.3). A $\beta$ stocks were sonicated for $5 \mathrm{~min}$ on ice, insoluble peptide aggregates were filtrated $\left(0.2 \mu \mathrm{m}\right.$ pore filter), and the stock was then kept at $+2{ }^{\circ} \mathrm{C}$ for storage. For experiments, the stocks were diluted into the same buffer that was used to fill the electrode, and once again, filtrated with a similar filter.

\subsection{Immunohistochemistry and Confocal Microscopy}

Immunostaining was performed using a protocol previously established in our laboratory [11]. Frozen $25 \mu \mathrm{m}$ or $15 \mu \mathrm{m}$ transverse sections from the skin photothrombosis area were generated. The sections were blocked with $5 \%$ normal goat serum $/ 5 \%$ normal horse serum (Vector Laboratories, Burlingame, CA, USA) in PBS containing 0.3\% Triton X-100 and $0.05 \%$ phenylhydrazine for 30 min, and then incubated with monoclonal mouse anti-A $\beta$ antibody with very low cross-reactivity to APP (diluted 1:1000; cat. \#LS-C181965, clone MOAB-2; LifeSpan Biosciences Inc., Seattle, WA, USA) in PBS-TAT $(0.3 \%$ TritonX-100, 5\% normal goat $/ 5 \%$ normal horse serum, $1 \%$ sodium azide, $0.01 \%$ thimerosal) overnight at $4{ }^{\circ} \mathrm{C}$. Fluorescein-5-isothiocyanate (FITC)-conjugated isolectin B4 (BSI-B4) from Bandeiraea simplicifolia (African climbing shrub; cat. \#L2895; Sigma-Aldrich; St. Louis, MO, USA) was used to mark endothelial cells to study colocalization of $A \beta$ with blood vessel boundaries. This isolectin is a known marker of the luminal surfaces of endothelial 
cells [52-54]. The sections were incubated with BSI-B4 $(20 \mu \mathrm{g} / \mathrm{mL})$, and the corresponding secondary antibodies (goat anti-mouse Alexa Fluor ${ }^{\circledR} 546$; Thermo Fisher Scientific, NY or fluorescein anti-mouse IgG; Vector Lab., Burlingame, CA, USA) overnight, rinsed twice in PBS, and visualized using an Olympus Fluoview FV1000 scanning inverted confocal microscope system equipped with a $60 \times / 1.43$ oil objective (Olympus, Melville, NY, USA). The images were analyzed using ImageJ software (http:/ /imagej.nih.gov/ij) with the Open Microscopy Environment Bio-Formats library and plugin, allowing for the opening of Olympus files (http:/ / www.openmicroscopy.org/site/support/ bio-formats5.4/). The data were analyzed using custom colorization.

\subsection{Enzyme-Linked Immunosorbent Assay (ELISA) Measurements}

A specialized, ready-to-use, mouse-specific, solid-phase sandwich ELISA kit (cat. \#KMB3481; Invitrogen) was used for direct measurement of the amount of $A \beta 40$ peptide in the skin with and without thrombosis. The skin samples were homogenized mechanically, and $100 \mathrm{mg}$ of homogenate was then lysed in guanidine solution ( $5 \mathrm{M}$ guanidine $\mathrm{HCl}, 50 \mathrm{mM}$ Tris $\mathrm{HCl}, \mathrm{pH} 8.0$ ). A monoclonal antibody to the $\mathrm{NH}_{2}$-terminus of mouse $\mathrm{A} \beta 40$ was coated onto the wells of the microtiter strips provided in the kit. Samples, including standards of known A $\beta 40$ content for calibration purposes as well as experimental specimens, were pipetted into the wells. After washing, the rabbit antibody specific to the $\mathrm{COOH}$-terminus of $\mathrm{A} \beta 40$ was added and detected with horseradish peroxidase-labelled anti-rabbit antibody. The optical density values at $450 \mathrm{~nm}$ were determined using a Wallac 1420 Victor2 Microplate Reader (PerkinElmer Inc., Waltham, MA, USA). A standard curve was used for final determination of the concentration of $A \beta 40$ in the samples, and is presented as picograms of $A \beta 40$ per milliliter of initial homogenate.

\subsection{Statistics and Measurements}

Using GraphPad Prism 7.03 (GraphPad Software, Inc., La Jolla, CA, USA) for calculations, an unpaired $t$-test was employed to estimate statistical differences. Values were determined to be significantly different if the two-tailed $p$ value was $<0.05$.

\section{Conclusions}

The results of the study suggest that $A \beta$ release in skin is associated with clot formation. $A \beta$ affects membrane conductance in yeast microorganisms, but not in mouse somatic cells. Just as clotting is denoted as a "normal" protection and repair process in damaged skin, so does the liberation of $A \beta$ during this process also lead to protection and repair. Skin-associated release of $A \beta$ may also have implications for the development of treatment methods to cure $A D$, as patients with compromised clotting, as in thrombophilia, thrombophlebitis, or similar conditions, could have additional inflammation problems from an anti-A $\beta$ vaccine. The development of the ACC-011 $A D$ vaccine (Elan-Wyeth Corp., Dublin, Ireland) was halted due to a patient developing skin lesions, which was identified as a suspected case of inflammation of skin blood vessels [84]. Another implication of systemic generation of $A \beta$ is the possible impact on the development of brain damage in $\mathrm{AD}$. This aspect was directly confirmed recently in a study using constant transfusion of blood between genetically modified animals that developed $A \beta$ plaques in the brain and their wild-type littermates. $A \beta$ originated from transgenic AD model mice entered the circulation and accumulated in the brains of wild-type mice [85].

Generation of $A \beta$ during thrombosis in the skin supports the hypothesis that $A \beta$ release is a natural defense against infection that may accompany skin trauma. In support of an $A \beta$ peptide role in natural antimicrobial defense, this study demonstrated that $A \beta$ directly affects the fungal cell external membrane while not affecting the host cell membrane at the same concentration. This remarkable specificity for microbes, with relatively low toxicity for host cells, was shown previously for many antimicrobial peptides from marine invertebrates [86], and we suggest that there is some similarity to the $\mathrm{A} \beta 40$ effect. 
Supplementary Materials: The following are available online at http:/ /www.mdpi.com/1422-0067/19/6/1705/ s1.

Author Contributions: L.Y.K, Y.V.K., A.V.W. and M.Y.I. conceived and designed the experiments; L.Y.K. and M.Y.I. performed the experiments; L.Y.K., Y.V.K. and M.Y.I. analyzed the data; M.Y.I. wrote the paper.

Acknowledgments: The authors wish to thank P. Sanabria for her help with absorbance measurements and A. Zayas-Santiago for her help with double immunostaining of skin slices. This research was supported by NIH grants 1SC1GM122691 to L.K. and 5SC2GM111149 to M.I. The funding sources had no role in study design; data collection, analysis, or interpretation; or the decision to submit this article.

Conflicts of Interest: The authors declare that they have no conflicts of interest. The founding sponsors had no role in the design of the study; in the collection, analyses, or interpretation of data; in the writing of the manuscript; and in the decision to publish the results.

\section{Abbreviations}

$\mathrm{A} \beta$ amyloid beta peptide Alzheimer's disease

\section{References}

1. Glenner, G.G.; Wong, C.W. Alzheimer's disease: Initial report of the purification and characterization of a novel cerebrovascular amyloid protein. Biochem. Biophys. Res. Commun. 1984, 120, 885-890. [CrossRef]

2. Askanas, V.; Engel, W.K.; Alvarez, R.B. Light and electron microscopic localization of $\beta$-amyloid protein in muscle biopsies of patients with inclusion-body myositis. Am. J. Pathol. 1992, 141, 31-36. [PubMed]

3. Askanas, V.; Alvarez, R.B.; Engel, W.K. $\beta$-Amyloid precursor epitopes in muscle fibers of inclusion body myositis. Ann. Neurol. 1993, 34, 551-560. [CrossRef] [PubMed]

4. McKinnon, S.J.; Lehman, D.M.; Kerrigan-Baumrind, L.A.; Merges, C.A.; Pease, M.E.; Kerrigan, D.F.; Ransom, N.L.; Tahzib, N.G.; Reitsamer, H.A.; Levkovitch-Verbin, H.; et al. Caspase activation and amyloid precursor protein cleavage in rat ocular hypertension. Investig. Ophthalmol. Vis. Sci. 2002, 43, 1077-1087.

5. Ito, Y.; Shimazawa, M.; Tsuruma, K.; Mayama, C.; Ishii, K.; Onoe, H.; Aihara, M.; Araie, M.; Hara, H. Induction of amyloid- $\beta(1-42)$ in the retina and optic nerve head of chronic ocular hypertensive monkeys. Mol. Vis. 2012, 18, 2647-2657. [PubMed]

6. Van Wijngaarden, P.; Hadoux, X.; Alwan, M.; Keel, S.; Dirani, M. Emerging ocular biomarkers of Alzheimer disease. Clin. Exp. Ophthalmol. 2017, 45, 54-61. [CrossRef] [PubMed]

7. Troncone, L.; Luciani, M.; Coggins, M.; Wilker, E.H.; Ho, C.Y.; Codispoti, K.E.; Frosch, M.P.; Kayed, R.; del Monte, F. A $\beta$ amyloid pathology affects the hearts of patients with Alzheimer's disease: Mind the heart. J. Am. Coll. Cardiol. 2016, 68, 2395-2407. [CrossRef] [PubMed]

8. Joachim, C.L.; Mori, H.; Selkoe, D.J. Amyloid $\beta$-protein deposition in tissues other than brain in Alzheimer's disease. Nature 1989, 341, 226-230. [CrossRef] [PubMed]

9. Heinonen, O.; Soininen, H.; Syrjänen, S.; Neittaanmäki, H.; Paljärvi, L.; Kosunen, O.; Syrjänen, K.; Riekkinen, P., Sr. $\beta$-Amyloid protein immunoreactivity in skin is not a reliable marker of Alzheimer's disease. An autopsy-controlled study. Arch. Neurol. 1994, 51, 799-804. [CrossRef] [PubMed]

10. Ono, S.; Matsuno, S.; Shimizu, N.; Shoji, S.; Tamaoka, A. Amyloid $\beta$ protein in skin of patients with amyotrophic lateral sclerosis. Lancet 1998, 351, 956-957. [CrossRef]

11. Kucheryavykh, L.Y.; Dávila-Rodríguez, J.; Rivera-Aponte, D.E.; Zueva, L.V.; Washington, A.V.; Sanabria, P.; Inyushin, M.Y. Platelets are responsible for the accumulation of $\beta$-amyloid in blood clots inside and around blood vessels in mouse brain after thrombosis. Brain Res. Bull. 2017, 128, 98-105. [CrossRef] [PubMed]

12. Bush, A.I.; Martins, R.N.; Rumble, B.; Moir, R.; Fuller, S.; Milward, E.; Currie, J.; David, A.; Andreas, W.; Fischer, R.; et al. The amyloid precursor protein of Alzheimer's disease is released by human platelets. J. Biol. Chem. 1990, 265, 15977-15983. [PubMed]

13. Van Nostrand, W.E.; Schmaier, A.H.; Farrow, J.S.; Cunningham, D.D. Protease nexin-II (amyloid $\beta$-protein precursor): A platelet $\alpha$-granule protein. Science 1990, 248, 745-748. [CrossRef] [PubMed]

14. Rosenberg, R.N.; Baskin, F.; Fosmire, J.A.; Risser, R.; Adams, P.; Svetlik, D.; Honig, L.S.; Cullum, C.M.; Weiner, M.F. Altered amyloid protein processing in platelets of patients with Alzheimer disease. Arch. Neurol. 1997, 54, 139-144. [CrossRef] [PubMed] 
15. Baskin, F.; Rosenberg, R.N.; Iyer, L.; Hynan, L.; Cullum, C.M. Platelet APP isoform ratios correlate with declining cognition in AD. Neurology 2000, 54, 1907-1909. [CrossRef] [PubMed]

16. Padovani, A.; Pastorino, L.; Borroni, B.; Colciaghi, F.; Rozzini, L.; Monastero, R.; Perez, J.; Pettenati, C.; Mussi, M.; Parrinello, G.; et al. Amyloid precursor protein in platelets: A peripheral marker for the diagnosis of sporadic AD. Neurology 2001, 57, 2243-2248. [CrossRef] [PubMed]

17. Van Nostrand, W.E.; Schmaier, A.H.; Farrow, J.S.; Cines, D.B.; Cunningham, D.D. Protease nexin-2/amyloid $\beta$-protein precursor in blood is a platelet-specific protein. Biochem. Biophys. Res. Commun. 1991, 175, 15-21. [CrossRef]

18. Ledesma, M.D.; da Silva, J.S.; Crassaerts, K.; Delacourte, A.; de Strooper, B.; Dotti, C.G. Brain plasmin enhances APP $\alpha$-cleavage and A $\beta$ degradation and is reduced in Alzheimer's disease brains. EMBO Rep. 2000, 1, 530-535. [CrossRef] [PubMed]

19. Schmaier, A.H. Alzheimer disease is in part a thrombohemorrhagic disorder. J. Thromb. Haemost. 2016, 14, 991-994. [CrossRef] [PubMed]

20. Zamolodchikov, D.; Renné, T.; Strickland, S. The Alzheimer's disease peptide $\beta$-amyloid promotes thrombin generation through activation of coagulation factor XII. J. Thromb. Haemost. 2016, 14, 995-1007. [CrossRef] [PubMed]

21. Chen, M.; Inestrosa, C.C.; Ross, G.S.; Fernandez, H.L. Platelets are the primary source of amyloid P-peptide in human blood. Biochem. Biophys. Res. Comrnun. 1995, 213, 96-103. [CrossRef] [PubMed]

22. Scheuner, D.; Eckman, C.; Jensen, M.; Song, X.; Citron, M.; Suzuki, N.; Bird, T.D.; Hardy, J.; Hutton, M.; Kukull, W.; et al. Secreted amyloid P-protein similar to that in the senile plaques of Alzheimer's disease is increased in vivo by the presenilin 1 and 2 and APP mutations linked to familial Alzheimer's disease. Nat. Med. 1996, 2, 864-870. [CrossRef] [PubMed]

23. Casoli, T.; di Stefano, G.; Giorgetti, B.; Grossi, Y.; Balietti, M.; Fattoretti, P.; Bertoni-Freddari, C. Release of $\beta$-amyloid from high-density platelets: Implications for Alzheimer's disease pathology. Ann. N. Y. Acad. Sci. 2007, 1096, 170-178. [CrossRef] [PubMed]

24. Soscia, S.J.; Kirby, J.E.; Washicosky, K.J.; Tucker, S.M.; Ingelsson, M.; Hyman, B.; Burton, M.A.; Goldstein, L.E.; Duong, S.; Tanzi, R.E.; et al. The Alzheimer's disease-associated amyloid $\beta$-protein is an antimicrobial peptide. PLoS ONE 2010, 5, e9505. [CrossRef] [PubMed]

25. Lukiw, W.J.; Cui, J.G.; Yuan, L.Y.; Bhattacharjee, P.S.; Corkern, M.; Clement, C.; Kammerman, E.M.; Ball, M.J.; Zhao, Y.; Sullivan, P.M.; et al. Acyclovir or A $\beta 42$ peptides attenuate HSV-1-induced miRNA-146a levels in human primary brain cells. Neuroreport 2010, 21, 922-927. [CrossRef] [PubMed]

26. White, M.R.; Kandel, R.; Tripathi, S.; Condon, D.; Qi, L.; Taubenberger, J.; Hartshorn, K.L. Alzheimer's associated $\beta$-Amyloid protein inhibits influenza a virus and modulates viral interactions with phagocytes. PLoS ONE 2014, 9. [CrossRef] [PubMed]

27. Bourgade, K.; Garneau, H.; Giroux, G.; Le Page, A.Y.; Bocti, C.; Dupuis, G.; Frost, E.H.; Fülöp, T., Jr. $\beta$-Amyloid peptides display protective activity against the human Alzheimer's disease-associated herpes simplex virus-1. Biogerontology 2014, 16, 85-98. [CrossRef] [PubMed]

28. Kumar, D.K.; Choi, S.H.; Washicosky, K.J.; Eimer, W.A.; Tucker, S.; Ghofrani, J.; Lefkowitz, A.; McColl, G.; Goldstein, L.E.; Tanzi, R.E.; et al. Amyloid- $\beta$ peptide protects against microbial infection in mouse and worm models of Alzheimer's disease. Sci. Transl. Med. 2016, 8. [CrossRef] [PubMed]

29. Inyushin, M.Y.; Sanabria, P.; Rojas, L.; Kucheryavykh, Y.; Kucheryavykh, L. A $\beta$ peptide originated from platelets promises new strategy in anti-Alzheimer's drug development. BioMed Res. Int. 2017. [CrossRef] [PubMed]

30. Yeaman, M.R.; Tang, Y.-Q.; Shen, A.J.; Bayer, A.S.; Selsted, M.E. Purification and in vitro activities of rabbit platelet microbicidal proteins. Infect. Immun. 1997, 65, 1023-1031. [PubMed]

31. Yeaman, M.R.; Ibrahim, A.S.; Edwards, J.E., Jr.; Bayer, A.S.; Ghannoum, M.A. Thrombin-induced rabbit platelet microbicidal protein is fungicidal in vitro. Antimicrob. Agents Chemother. 1993, 37, 546-553. [CrossRef] [PubMed]

32. Krijgsveld, J.; Zaat, S.A.; Meeldijk, J.; van Veelen, P.A.; Fang, G.; Poolman, B.; Brandt, E.; Ehlert, J.E.; Kuijpers, A.J.; Engbers, G.H.; et al. Thrombocidins, microbicidal proteins from human blood platelets, are C-terminal deletion products of CXC chemokines. J. Biol. Chem. 2000, 275, 20374-20381. [CrossRef] [PubMed] 
33. Kupferwasser, L.I.; Yeaman, M.R.; Shapiro, S.M.; Nast, C.C.; Bayer, A.S. In vitro susceptibility to thrombin-induced platelet microbicidal protein is associated with reduced disease progression and complication rates in experimental Staphylococcus aureus endocarditis: Microbiological, histopathologic, and echocardiographic analyses. Circulation 2002, 105, 746-752. [PubMed]

34. Tang, Y.Q.; Yeaman, M.R.; Selsted, M.E. Antimicrobial peptides from human platelets. Infect. Immun. 2002, 70, 6524-6533. [CrossRef] [PubMed]

35. Yount, N.Y.; Gank, K.D.; Xiong, Y.Q.; Bayer, A.S.; Pender, T.; Welch, W.H.; Yeaman, M.R. Platelet microbicidal protein 1: Structural themes of a multifunctional antimicrobial peptide. Antimicrob. Agents Chemother. 2004, 48, 4395-4404. [CrossRef] [PubMed]

36. Kawahara, M.; Arispe, N.; Kuroda, Y.; Rojas, E. Alzheimer's disease amyloid $\beta$-protein forms $\mathrm{Zn}^{2+}$-sensitive, cation-selective channels across excised membrane patches from hypothalamic neurons. Biophys. J. 1997, 73, 67-75. [CrossRef]

37. Lin, H.; Bhatia, R.; Lal, R. Amyloid $\beta$ protein forms ion channels: Implications for Alzheimer's disease pathophysiology. FASEB J. 2001, 15, 2433-2444. [CrossRef] [PubMed]

38. Lal, R.; Lin, H.; Quist, A.P. Amyloid $\beta$ ion channel: 3D structure and relevance to amyloid channel paradigm. Biochim. Biophys. Acta 2007, 1768, 1966-1975. [CrossRef] [PubMed]

39. Kawahara, M. Neurotoxicity of $\beta$-amyloid protein: Oligomerization, channel formation, and calcium dyshomeostasis. Curr. Pharm. Des. 2010, 16, 2779-2789. [CrossRef] [PubMed]

40. Harder, J.; Bartels, J.; Christophers, E.; Schröder, J.-M. A peptide antibiotic from human skin. Nature 1997, 387, 861. [CrossRef] [PubMed]

41. Hancock, R.E.W.; Chapple, D.S. Peptide antibiotics. Antimicrob. Agents Chemother. 1999, 43, $1317-1323$. [CrossRef]

42. Lan, J.; Liu, J.; Zhao, Z.; Xue, R.; Zhang, N.; Zhang, P.; Zhao, P.; Zheng, F.; Sun, X. The peripheral blood of A $\beta$ binding RBC as a biomarker for diagnosis of Alzheimer's disease. Age Ageing 2015, 44, 458-464. [CrossRef] [PubMed]

43. Mohanty, J.G.; Eckley, D.M.; Williamson, J.D.; Launer, L.J.; Rifkind, J.M. Do red blood cell- $\beta$-amyloid interactions alter oxygen delivery in Alzheimer's disease? Adv. Exp. Med. Biol. 2008, 614, 29-35. [PubMed]

44. Inyushin, M.Y.; Tsytsarev, V.Y.; Ignashchenkova, A.Y.; Lenkov, D.N. Use of artificial ion channels for quasi-intracellular recording of cerebral cortex neuron activity. Neurosci. Behav. Physiol. 1997, 27, 702-707. [CrossRef] [PubMed]

45. Miloshevsky, G.V.; Jordan, P.C. The open state gating mechanism of gramicidin a requires relative opposed monomer rotation and simultaneous lateral displacement. Structure 2006, 14, 1241-1249. [CrossRef] [PubMed]

46. Watson, B.D.; Dietrich, W.D.; Busto, R.; Wachtel, M.S.; Ginsberg, M.D. Induction of reproducible brain infarction by photochemically initiated thrombosis. Ann. Neurol. 1985, 17, 497-504. [CrossRef] [PubMed]

47. Youmans, K.L.; Tai, L.M.; Kanekiyo, T.; Stine, W.B., Jr.; Michon, S.C.; Nwabuisi-Heath, E.; Manelli, A.M.; Fu, Y.; Riordan, S.; Eimer, W.A.; et al. Intraneuronal A $\beta$ detection in $5 x F A D$ mice by a new A $\beta$-specific antibody. Mol. Neurodegener. 2012, 7, 8. [CrossRef] [PubMed]

48. Collins, J.M.; King, A.E.; Woodhouse, A.; Kirkcaldie, M.T.; Vickers, J.C. The effect of focal brain injury on $\beta$-amyloid plaque deposition, inflammation and synapses in the APP/PS1 mouse model of Alzheimer's disease. Exp. Neurol. 2015, 267, 219-229. [CrossRef] [PubMed]

49. Ismail, J.A.; Poppa, V.; Kemper, L.E.; Scatena, M.; Giachelli, C.M.; Coffin, J.D.; Murry, C.E. Immunohistologic labeling of murine endothelium. Cardiovasc. Pathol. 2003, 12, 82-90. [CrossRef]

50. DeLisser, H.M.; Newman, P.J.; Albelda, S.M. Platelet endothelial cell adhesion molecule (CD31). Curr. Top. Microbiol. Immunol. 1993, 184, 37-45. [PubMed]

51. Bryckaert, M.; Rosa, J.P.; Denis, C.V.; Lenting, P.J. Of von Willebrand factor and platelets. Cell. Mol. Life Sci. 2015, 72, 307-326. [CrossRef] [PubMed]

52. Laitinen, L. Griffonia simplicifolia lectins bind specifically to endothelial cells and some epithelial cells in mouse tissues. Histochem. J. 1987, 19, 225-234. [CrossRef] [PubMed]

53. Hansen-Smith, F.M.; Watson, L.; Lu, D.Y.; Goldstein, I. Griffonia simplicifolia I: Fluorescent tracer for microcirculatory vessels in nonperfused thin muscles and sectioned muscle. Microvasc. Res. 1988, 36, $199-215$. [CrossRef] 
54. Hirabayashi, J. Lectins: Methods and Protocols, Methods in Molecular Biology; Springer: New York, NY, USA, 2014; Volume 1200, pp. 1-667.

55. Cho, S.M.; Lee, S.; Yang, S.H.; Kim, H.Y.; Lee, M.J.; Kim, H.V.; Kim, J.; Baek, S.; Yun, J.; Kim, D.; et al. Age-dependent inverse correlations in CSF and plasma amyloid- $\beta$ (1-42) concentrations prior to amyloid plaque deposition in the brain of 3xTg-AD mice. Sci. Rep. 2016, 6, 20185. [CrossRef] [PubMed]

56. Ruiz, A.; Pesini, P.; Espinosa, A.; Pérez-Grijalba, V.; Valero, S.; Sotolongo-Grau, O.; Alegret, M.; Monleón, I.; Lafuente, A.; Buendía, M.; et al. Blood amyloid $\beta$ levels in healthy, mild cognitive impairment and Alzheimer's disease individuals: Replication of diastolic blood pressure correlations and analysis of critical covariates. PLoS ONE 2013, 8, e81334. [CrossRef] [PubMed]

57. Emadi, S.; Aghababaee, L.; Maghbooli, M. Serum concentration of $\beta$ amyloid peptide and the activity of angiotensin converting enzyme in Alzheimer's disease patients: Search for a potential biomarker. Int. J. Res. Med. Sci. 2016, 4, 421-427. [CrossRef]

58. Fukumoto, H.; Tennis, M.; Locascio, J.J.; Hyman, B.T.; Growdon, J.H.; Irizarry, M.C. Age but not diagnosis is the main predictor of plasma amyloid $\beta$-protein levels. Arch. Neurol. 2003, 60, 958-964. [CrossRef] [PubMed]

59. Aluise, C.D.; Sowell, R.A.; Butterfield, D.A. Peptides and proteins in plasma and cerebrospinal fluid as biomarkers for the prediction, diagnosis, and monitoring of therapeutic efficacy of Alzheimer's disease. Biochim. Biophys. Acta 2008, 1782, 549-558. [CrossRef] [PubMed]

60. Bertl, A.; Bihler, H.; Kettner, C.; Slayman, C.L. Electrophysiology in the eukaryotic model cell Saccharomyces cerevisiae. Pflugers Arch. 1998, 436, 999-1013. [CrossRef] [PubMed]

61. Farkas, V. Structure and biosynthesis of fungal cell walls: Methodological approaches. Folia Microbiol. 2003, 48, 469-478. [CrossRef]

62. Arispe, N.; Rojas, E.; Pollard, H.B. Alzheimer disease amyloid $\beta$ protein forms calcium channels in bilayer membranes: Blockade by tromethamine and aluminum. Proc. Natl. Acad. Sci. USA 1993, 90, 567-571. [CrossRef] [PubMed]

63. Sepulveda, F.J.; Parodi, J.; Peoples, R.W.; Opazo, C.; Aguayo, L.G. Synaptotoxicity of Alzheimer $\beta$ amyloid can be explained by its membrane perforating property. PLoS ONE 2010, 5, e11820. [CrossRef] [PubMed]

64. Martinez-Hernandez, A.; Urbanke, H.; Gillman, A.L.; Lee, J.; Ryazanov, S.; Agbemenyah, H.Y.; Benito, E.; Jain, G.; Kaurani, L.; et al. The diphenylpyrazole compound anle138b blocks A $\beta$ channels and rescues disease phenotypes in a mouse model for amyloid pathology. EMBO Mol. Med. 2018, 10, 32-47. [CrossRef] [PubMed]

65. Morioka, S.; Shigemori, T.; Hara, K.; Morisaka, H.; Kuroda, K.; Ueda, M. Effect of sterol composition on the activity of the yeast G-protein-coupled receptor Ste2. Appl. Microbiol. Biotechnol. 2013, 97, 4013-4020. [CrossRef] [PubMed]

66. Arispe, N.; Doh, M. Plasma membrane cholesterol controls the cytotoxicity of Alzheimer's disease A $\beta P$ (1-40) and (1-42) peptides. FASEB J. 2002, 16, 1526-1536. [CrossRef] [PubMed]

67. de Planque, M.R.; Raussens, V.; Contera, S.A.; Rijkers, D.T.; Liskamp, R.M.; Ruysschaert, J.M.; Ryan, J.F.; Separovic, F.; Watts, A. $\beta$-Sheet structured $\beta$-amyloid(1-40) perturbs phosphatidylcholine model membranes. J. Mol. Biol. 2007, 368, 982-997. [CrossRef] [PubMed]

68. Kagan, B.L.; Thundimadathil, J. Amyloid peptide pores and the $\beta$ sheet conformation. Adv. Exp. Med. Biol. 2010, 677, 150-167. [PubMed]

69. Ryan, T.M.; Caine, J.; Mertens, H.D.; Kirby, N.; Nigro, J.; Breheney, K.; Waddington, L.J.; Streltsov, V.A.; Curtain, C.; Masters, C.L.; et al. Ammonium hydroxide treatment of A $\beta$ produces an aggregate free solution suitable for biophysical and cell culture characterization. PeerJ 2013, 1, e73. [CrossRef] [PubMed]

70. Porzoor, A.; Caine, J.M.; Macreadie, I.G. Pretreatment of chemically-synthesized A $\beta 42$ affects its biological activity in yeast. Prion 2014, 8, 404-410. [CrossRef] [PubMed]

71. Kuo, Y.M.; Kokjohn, T.A.; Kalback, W.; Luehrs, D.; Galasko, D.R.; Chevallier, N.; Koo, E.H.; Emmerling, M.R.; Roher, A.E. Amyloid- $\beta$ peptides interact with plasma proteins and erythrocytes: Implications for their quantitation in plasma. Biochem. Biophys. Res. Commun. 2000, 268, 750-756. [CrossRef] [PubMed]

72. Roher, A.E.; Esh, C.L.; Kokjohn, T.A.; Castaño, E.M.; van Vickle, G.D.; Kalback, W.M.; Patton, R.L.; Luehrs, D.C.; Daugs, I.D.; Kuo, Y.M.; et al. Amyloid $\beta$ peptides in human plasma and tissues and their significance for Alzheimer's disease. Alzheimers Dement. 2009, 5, 18-29. [CrossRef] [PubMed]

73. Toledo, J.B.; Shaw, L.M.; Trojanowski, J.Q. Plasma amyloid $\beta$ measurements-A desired but elusive Alzheimer's disease biomarker. Alzheimers Res. Ther. 2013, 5, 8. [CrossRef] [PubMed] 
74. Sanan, D.A.; Weisgraber, K.H.; Russell, S.J.; Mahley, R.W.; Huang, D.; Saunders, A.; Schmechel, D.; Wisniewski, T.; Frangione, B.; Roses, A.D. Apolipoprotein E associates with $\beta$ amyloid peptide of Alzheimer's disease to form novel monofibrils. Isoform apoE4 associates more efficiently than apoE3. J. Clin. Investig. 1994, 94, 860-869. [CrossRef] [PubMed]

75. Arispe, N.; Pollard, H.B.; Rojas, E. $\beta$-Amyloid Ca ${ }^{2+}$-channel hypothesis for neuronal death in Alzheimer disease. Mol. Cell. Biochem. 1994, 140, 119-125. [CrossRef] [PubMed]

76. Fenjves, E.S.; Gordon, D.A.; Pershing, L.K.; Williams, D.L.; Taichman, L.B. Systemic distribution of apolipoprotein E secreted by grafts of epidermal keratinocytes: Implications for epidermal function and gene therapy. Proc. Natl. Acad. Sci. USA 1989, 86, 8803-8807. [CrossRef] [PubMed]

77. Barra, R.M.; Fenjves, E.S.; Taichman, L.B. Secretion of apolipoprotein E by basal cells in cultures of epidermal keratinocytes. J. Investig. Dermatol. 1994, 102, 61-66. [CrossRef] [PubMed]

78. Citron, M.; Vigo-Pelfrey, C.; Teplow, D.B.; Miller, C.; Schenk, D.; Johnston, J.; Winblad, B.; Venizelos, N.; Lannfelt, L.; Selkoe, D.J. Excessive production of amyloid $\beta$-protein by peripheral cells of symptomatic and presymptomatic patients carrying the Swedish familial Alzheimer disease mutation. Proc. Natl. Acad. Sci. USA 1994, 91, 11993-11997. [CrossRef] [PubMed]

79. Furumoto, H.; Shimizu, T.; Asagami, C.; Muto, M.; Takahashi, M.; Hoshii, Y.; Ishihara, T.; Nakamura, K. Apolipoprotein $\mathrm{E}$ is present in primary localized cutaneous amyloidosis. J. Investig. Dermatol. 1998, 111, 417-421. [CrossRef] [PubMed]

80. Hashimoto, K.; Ito, K.; Taniguchi, Y.; Yang, F.; Youngberg, G. Keratin in cutaneous amyloidoses. Clin. Dermatol. 1990, 8, 55-65. [CrossRef]

81. Furumoto, H.; Hashimoto, Y.; Muto, M.; Shimizu, T.; Nakamura, K. Apolipoprotein E4 is associated with primary localized cutaneous amyloidosis. J. Investig. Dermatol. 2002, 119, 532-533. [CrossRef] [PubMed]

82. Corder, E.H.; Saunders, A.M.; Strittmatter, W.J.; Schmechel, D.E.; Gaskell, P.C.; Small, G.W.; Roses, A.D.; Haines, J.L.; Pericak-Vance, M.A. Gene dose of apolipoprotein E type 4 allele and the risk of Alzheimer's disease in late onset families. Science 1993, 261, 921-923. [CrossRef] [PubMed]

83. Lee, J.S.; Lee, B.I.; Park, C.B. Photo-induced inhibition of Alzheimer's $\beta$-amyloid aggregation in vitro by rose Bengal. Biomaterials 2015, 38, 43-49. [CrossRef] [PubMed]

84. Hollingsworth, C. Elan-Wyeth Alzheimer's Trial Suspended Due to Skin Lesion. BioWorld Today, 21 April 2008. Available online: www.bioworld.com (accessed on 23 April 2015).

85. Bu, X.L.; Xiang, Y.; Jin, W.S.; Wang, J.; Shen, L.L.; Huang, Z.L.; Zhang, K.; Liu, Y.H.; Zeng, F.; Liu, J.H.; et al. Blood-derived amyloid- $\beta$ protein induces Alzheimer's disease pathologies. Mol. Psychiatry 2017. [CrossRef] [PubMed]

86. Tincu, J.A.; Taylor, S.W. Antimicrobial peptides from marine invertebrates. Antimicrob. Agents Chemother. 2004, 48, 3645-3654. [CrossRef] [PubMed]

(C) 2018 by the authors. Licensee MDPI, Basel, Switzerland. This article is an open access article distributed under the terms and conditions of the Creative Commons Attribution (CC BY) license (http://creativecommons.org/licenses/by/4.0/). 